\title{
MRI characterization of cerebral dysgenesis in maternal PKU
}

\author{
RJ Allen, J Brunberg, E Schwartz, AM Schaefer and G Jackson \\ Divisions of Pediatric Neurology and Neuroradiology, University of Michigan Medical School, Ann Arbor, MI, USA
}

\begin{abstract}
Allen RJ, Brunberg J, Schwartz E, Schaefer AM, Jackson G. MRI characterization of cerebral dysgenesis in maternal PKU. Acta Pædiatr 1994;(Suppl 407):83-5. Stockholm. ISSN 0803-5326

MPKU pregnancies, with or without dietary treatment to reduce maternal plasma phenylalanine (phe), show variable, increased non-physiologic levels, as the putative cause of fetal teratogenicity. Cerebral dysgenesis with clinical neonatal microcephaly and congenital heart disease indicates altered organ morphogenesis. Although there is not an established precise relations?ip between maternal phe levels and outcome, dietary restriction before or early in gestation is universally advised. Both human experience and animal research have suggested differential organ responses to high and low phe levels. Structural micrencephaly may be due to reduced brain volume or abnormal regional brain development. Infants in MPKU are also at risk to develop PKU. Micrencephaly was evident by MRI in 8 of 21 infants born to 12 MPKU mothers; 2 infants of one mother developed PKU. All levels of gestational plasma phe were associated with otherwise structurally normal infant micrencephalic brains appropriate for age in myelination. CHD occurred in one micrencephalic infant of a classic MPKU treated in the first trimester. Maternal, cord and neonatal plasma phenylalanine at delivery did not correlate with teratogenic effects. Only untreated 'classic' MPKU fetal effects appear predictable.
\end{abstract}

RJ Allen, Department of Pediatric Neurology, University of Michigan Medical School, Ann Arbor, MI, USA.

Gestational hyperphenylalaninemia (HPA) in maternal phenyl ketonuria (MPKU) is the putative cause of fetal teratogenicity in the fetal phenylalanine syndrome. Mental retardation $(21-92 \%)$ and microcephaly $(24-73 \%)$ are the major neurologic effects, often associated with low birth weight and congenital heart disease $(12 \%)(1)$. Cerebral dysgenesis causing brain malformations related to microcephaly occurs at specific periods of neurogenesis, cell proliferation and neuronal migration. Disorders of neuronal migration (NMD) occur in the first half of gestation as neurons migrate between 12 and 20 weeks. Cell growth, arborization, synaptogenesis (dendritic development), gliogenesis and myelination follow in the second half of gestation. Abnormal dendritic synaptogenesis is related to mental retardation (2). Other associated organ malformations, such as congenital heart defects (CHD) and syndactyly have different ontogenetic expressions.

In experimental animal dementiar, various "toxins" (ethanol and methylazoxymethanol (MAM)) on specific gestational days (G14-16) caused the structural brain changes of micrencephaly (3). Cerebral cortical gliogenesis occurred after $\mathrm{G} 16$. In a dose-response effect, for example, altered cerebellar Purkinje cell density appears only with high ethanol blood levels while low levels in the first weeks of gestation have no effect. Experimental hyperphenylalaninemia in pregnant rats disturbs synaptogenesis on gestational days G1-G21. Cardiac malformations developed later on days G8-G11, suggesting a dose responsiveness $(4,5)$.

While potentially all untreated PKU women are at gestational fetal risk, the benefits of dietary phenylalanine restriction have not been precisely related to specific ontogenetic times, and uncertainty persists regarding the dose-response relationship. Dendritic abnormalities, however, have been identified in a single infant brain examined following neonatal cardiac death in MPKU (6). Golgi preparations demonstrated immature cortical pyramidal cell somata and dendritic spines.

In vivo, $C N S$ magnetic resonance imaging (MRI) and positron emission tomography (PET) in children are useful in evaluating cerebral dysgenesis such as lissencephaly as well as neuropsychiatric disorders such as autism. In infantile autism, the precise methodology in neuroanatomic measurements is necessary to establish concordance in autopsy and MRI as evidence of neuroanatomic maldevelopment. MRI is useful in examining various clinical types of PKU, including the putative effects of diet (7). [ $\left.{ }^{18} \mathrm{~F}\right]$ fluoro-2-deoxy-Dglucose positron emission tomography $\left({ }^{18} \mathrm{FDG}-\mathrm{PET}\right)$ can provide information on brain function in $\mathrm{PKU}$ dementia and disorders of cerebral dysgenesis $(8-10)$.

\section{Patients and methods}

Since the advent of newborn screening (NBS) in 1965, 
Table 1. Characteristics of the 21 MPKU infants and 12 mothers (1955-1994).

\begin{tabular}{|c|c|c|c|c|c|}
\hline MPKU HPA & $\begin{array}{c}\text { Infants }(n=21) \\
\text { and mothers }(n=12)\end{array}$ & $\begin{array}{l}\text { Microcephaly at } \\
\text { or }<5 \% \text { ile }\end{array}$ & $\begin{array}{c}\text { Dementia } \\
((\text { No. infants }) \text { and IQ) }\end{array}$ & CHD/dysmorphology & $\begin{array}{c}\text { MRI (7) } \\
\text { ((No. infants) and age) }\end{array}$ \\
\hline $\begin{array}{l}\text { Classic } \\
\quad(>20 \mathrm{mg} / \mathrm{dl} \\
(1200 \mu \mathrm{mol} / \mathrm{l}))\end{array}$ & $\begin{array}{l}9 \text { infants/ } \\
4 \text { mothers } \\
(1 \mathrm{Rx}-\Delta: 1 / \\
2 \mathrm{RX}-\Delta: 2)\end{array}$ & (9) $100 \%$ & $\begin{array}{l}\text { (9) } 43-84 \\
\text { (mean 63) }\end{array}$ & $\begin{array}{l}\text { (1) (CHD + } \\
\text { syndactyly) }\end{array}$ & $\begin{array}{l}\text { (1) } 1 \mathrm{~m}, 6 \mathrm{~m} \\
\text { (1) } 3 \mathrm{wk}, 19 \mathrm{~m} \\
\text { (1) } 8 \mathrm{yr} \\
\text { (1) } 5 \mathrm{yr} \\
\text { Normal }\end{array}$ \\
\hline $\begin{array}{l}\text { Mild } \\
(10-20 \mathrm{mg} / \mathrm{dl} \\
\quad(600-1200 \\
\mu \mathrm{mol} / \mathrm{l}))\end{array}$ & $\begin{array}{l}4 \text { infants/ } \\
2 \text { mothers } \\
\text { (2 pregnant) } \\
\text { No treatment }\end{array}$ & (4) $100 \%$ & $\begin{array}{l}\text { (3) } 55-105 \\
\text { (mean } 75 \text { ) }\end{array}$ & 0 & $\begin{array}{l}\text { (1) } 21 \text { days } \\
\text { (1) } 5 \mathrm{~m} \\
\text { Normal }\end{array}$ \\
\hline $\begin{array}{l}\text { Benign } \\
\quad(<\mathrm{HPA}: \\
10 \mathrm{mg} / \mathrm{dl} \\
(600 \mu \mathrm{mol} / \mathrm{l}))\end{array}$ & $\begin{array}{l}8 \text { infants/ } \\
6 \text { mothers } \\
\text { ( } 5 \text { pregnant) } \\
\text { No treatment }\end{array}$ & $\begin{array}{l}\text { (2) }<5 \text { th } \\
\text { (3) } 10-25 \text { th } \\
\text { (1) } 50 \text { th } \\
\text { (1) } 75-90 \text { th } \\
71 \%<25 \% \text { ile }\end{array}$ & $\begin{array}{l}\text { (3) } 83-110 \\
\text { (mean 94) }\end{array}$ & (2) PKU & $\begin{array}{l}\text { (1) } 1.5 \mathrm{~m} \\
\text { (and sib + PKU) } \\
\text { Normal }\end{array}$ \\
\hline
\end{tabular}

nearly 400 PKU infants have been detected and followed into adolescence and adulthood in our pediatric neurology metabolic clinic. Long-term experiences in this population as well as other adults born before NBS form the basis for the neurological concern for the progeny of MPKU managed by presently available therapeutic measures. Neurological, psychological, metabolic and nutritional services are provided by a grant from the Department of Public Health. Home monitoring of plasma phenylalanine has been facilitated by HPLC technology. Simplified blood collections for amino acid quantitation, regardless of frequency, is provided at no cost to families or MPKU adults. Special formulas for diet treatment are also provided at no cost. MRI studies in all patients are part of routine neurological assessments, with written informed consent, together with psychological testing to determine neurological CNS status.

For family planning, adolescents and adults of both genders are concerned about the genetic implications of PKU. MPKU is increasing in frequency as the treated population ages with an increasing number of unplanned pregnancies. A few adult women born before 1965 learned of the diagnosis of PKU only after giving birth to affected infants. This mixture of PKU ascertainment provides an insight into the limitations of outpatient care, during gestation, and in long-term follow-up of fetal CNS effects.

\section{Results}

This MPKU study was concerned with the fetal phenylalanine syndrome and routinely offered head MRI to parents of microcephalic (head circumference $<5 \%$ tile) infants to identify cerebral dysgenesis (micrencephaly). Table 1 shows the neurological effects and associated anomalies with (1) biochemical severity and (2) treat- ment compliance, related to MRI examinations. All infants born to untreated MPKU mothers with either severe or mild (variant) PKU were clinically affected with head circumferences below the 5 th percentile. The infant of one mother treated with excellent compliance in the second and third trimesters presented with severe microcephaly, growth failure, congenital heart disease and syndactyly. A second mother delivered two children, now 5 and 8 years of age, prior to the discovery of MPKU; both the mother and children were examined by MRI. Two classic PKU mothers showed periventricular white matter changes with normal MRI examinations in the children. In mild, untreated MPKU, there is a similar frequency of microcephaly without other malformations, suggesting a tissue specific dose-response threshold effect. In benign MPKU (HPA), two children of one mother were affected with classic PKU and benign HPA and one child was microcephalic.

A total of seven brain MRI (1.5-T) studies in children varying in age from 3 weeks to 8 years did not reveal structural brain abnormalities; mild reduced brain volume was evident in one older child.

\section{Discussion}

Cerebral dysgenesis in the MPKU fetal phenylalanine syndrome is not evident from brain MRI studies. Microscopic changes in dendritic spine structure have been reported in a single infant brain by histologic examination. A similar syndrome of structurally normal microcephaly by MRI has been observed in the second child of a mother on chronic total parenteral nutrition during gestation compared with the normal first child before the need for long-term alternative nutrition was introduced. We have previously reported normal brain distribution of ${ }^{18}$ FDG by PET examination, including the interference by phenylalanine of the 
transport of a labeled analog. Disturbed placental and blood-brain barrier transport are important putative mechanisms in the high fetal/maternal gradient of phenylalanine. Developmental changes in specialized neurons of biogenic amine metabolism during early fetal life may have an important role in CNS gestational effects on synaptogenesis since catecholaminergic neurons mature in early fetal life. Neurotransmitter receptor markers parallel the course of elaboration of axons and dendrites during fetal development.

The past 30 years' experience with MPKU is not encouraging. Unplanned pregnancies are frequent in spite of years of family counselling and biochemical monitoring. A worldwide effort to correct HPA during MPKU gestation is well documented in the scientific literature. In our experience adherence to strict diets with frequent blood phenylalanine surveillance and nutritional supervision, in an outpatient environment, provides inadequate precision of physiologic levels of plasma amino acids. Microcephalic infants with reduced intelligence are a common outcome. The ultimate long-term impact on society may not be known for generations. To date, collection of maternal biochemical data during gestation and in the perinatal period does not provide useful insight into fetal developmental neurobiology. Innovative approaches in fetal and gestational nutritional biology are necessary.

New in-vivo neuroimaging technology (MRI, PET and magnetic resonance spectroscopy (MRS) (11)) is available for appropriate application in seeking the solution to MPKU brain effects. Extending research to animal model dementias may also provide useful clues to clinical management. Alternative therapeutic models such as diet supplementation in animal model experiments including the transport of competitive amino acids or the addition of cell growth factors, rather than diet restriction, are essential in revising the course of abnormal neurological outcome now taking place in MPKU.

\section{References}

1. Lenke RR, Levy HL. Maternal phenylketonuria and hyperphenylalaninemia. N Engl J Med 1980;20:1202-8

2. Purpura DP. Dendritic spine 'dysgenesis' and mental retardation. Science $1974 ; 186: 1126-8$

3. Ferrer I. Experimentally induced cortical malformations in rats Child Nerv Syst 1993;9:403-7

4. Chase HP, O'Brien D. Effect of excess phenylalanine and of other amino acids on brain development in the infant rat. Pediatr Res 1970;4:96-102

5. Suyama I, Tani M, Fatsumura M, Isshiki G, Okano Y, Oura T et al. Fetal heart malformations in experimental hyperphenylalaninemia in pregnant rats. Congenital Anomalies 1989; 29:15-29

6. Lacey DJ, Terplan K. Abnormal cerebral cortical neurons in a child with maternal PKU syndrome. J Child Neurol 1987;2:201-4

7. Pearson KD, Gean-Marton AD, Levy HL, Davis KR. PKU: MRI of the brain with clinical correlation. Radiology 1990; 177:437-40

8. Lee N, Radtke RA, Gray L, Burger PC, Montine TJ, DeLong $\mathrm{GR}$, et al. Neuronal migration disorders: positron emission tomography correlations. Ann Neurol 1994:35:290-7

9. Allen RJ, Gebarski S, Aisen A. MRI in genetic metabolic diseases: diagnostic and therapeutic implications. Pediatr Res 1985;19:387A

10. Kollros P, Allen RJ, Shulkin B, Koeppe R, Schaefer AM, Giordani B, et al. Positron-emission tomographic scanning of cerebral metabolism in classic PKU. Ann Neurol 1989;26:435A

11. Kauppinen RA, Williams SR, Busza AL, van Bruggen N, Applications of magnetic resonance spectroscopy and diffusionweighted imaging to the study of brain biochemistry and pathology. Trends Neurosci 1993;16:88-95 